\title{
Application of solid lipid nanoparticles preparation in infection caused by antibiotic-resistant bacteria
}

\author{
Nenes Prastiwi ${ }^{1,2,}$ Ervina $^{1}$, Kezia Josawel Lesbatta ${ }^{1}$ \\ ${ }^{1}$ Master of Biomedical Sciences, Faculty of Medicine, Public Health, and Nursing, Universitas \\ Gadjah Mada, ${ }^{2}$ Department of Microbiology, Faculty of Medicine, Public Health, and Nursing \\ Universitas Gadjah Mada, Yogyakarta \\ https://doi.org/10.22146/ijpther.2318
}

\section{ABSTRACT}

Submitted: 06/08/2021

Accepted : 19/11/2021

Keywords:

antimicrobial resistance; antibiotics;

drug delivery systems;

nanomedicine;

solid lipid nanoparticles;
Solid lipid nanoparticles (SLN) is a potential alternative method for drug delivery due to its good stability, low toxicity, can be modified and controlled in drug release, as well as can be produced on a large scale. The SLNs are composed of solid lipids stabilized by emulsifiers. The lipids used for SLN are physiological lipids that easily tolerated by the body. These characteristics make SLN as a potential delivery system that can increase the efficiency of an antibiotics preparation. The development of bacterial resistance to antibacterial has become serious health problems in infectious diseases. Solid lipid nanoparticles is a compelling choice as a drug delivery system that can reduce the problem of the bacterial resistance. This review discussed the role of SLN as a drug carrier system which includes the characteristics and structure of SLN, its pharmacokinetic properties, bacterial resistance mechanism, and SLN mechanism in reducing bacterial resistance.

\begin{abstract}
ABSTRAK
Nanopartikel solid lipid (solid lipid nanoparticle/SLN) merupakan metode alternatif penghantaran obat yanga potensial karena stabilitasnya yang baik, toksisitasnya rendah, dapat dimodifikasi dan dikendalikan pelepasan obatnya, serta dapat diproduksi dalam skala besar. Nanopartikel solid lipid tersusun dari lipid padat yang distabilkan oleh pengemulsi. Lipid yang digunakan untuk SLN merupakan lipid fisiologis yang ditoleransi oleh tubuh. Karakteristik tersebut menjadikan SLN sebagai sistem penghantaran potensial untuk meningkatkan efisiensi sediaan antibiotik. Perkembangan bakteri yang resisten terhadap antibiotik telah menjadi masalah kesehatan yang serius dalam penyakit infeksi. Nanopartikel solid lipid menjadi pilihan sebagai sistem penghantaran obat yang dapat mengurangi masalah resistensi antibiotik. Dalam ulasan ini, dibahas peran SLN sebagai sistem penghantar obat yang mencakup karakteristik dan struktur SLN, sifat farmakokinetik, mekanisme resistensi bakteri, dan mekanisme SLN dalam menurunankan kemampuan resisten mikroba.
\end{abstract}

\section{INTRODUCTION}

Nanoparticles are used in medical treatment as drug carrier in various diseases. Lipid-based nanoparticles use in drug delivery systems were discovered early on by professor RH Müller from Germany and professor M. Gascon from Italy since the early $19^{\text {th }}$ century. ${ }^{1}$ Nanoparticles are produced with nanosized structures by pharmaceutical nanotechnology, to deliver drugs in particles that can be easily absorbed and provide a pharmacological response with minimal side effects. ${ }^{2}$

The advantages of lipid-based nanoparticles are ease of production on a large scale, non-toxicity, controlled drug release, and increased drug solubility. ${ }^{3}$ The use of lipid-based solid nanoparticles as an antibiotic delivery agent is quite promising in overcoming drug resistance problems. Bacterial resistance to antibiotics can occur 
when bacteria develop the ability to evade the effects of drugs that can inhibit growth or kill bacteria. The high number of antibiotic resistance has prompted the development of various strategies to overcome multidrugresistant (MDR) bacteria. One of them is by utilizing an optimization approach to the pharmacokinetic profile of drugs through nanoparticles. This approach can be applied to overcome the problem of bacterial resistance. ${ }^{4}$

The use of nanoparticles in improving the effectiveness of various therapeutic drugs in complex diseases, such as cancer and autoimmune diseases, has provided new solutions in the development of drug delivery systems for the treatment of infections caused by MDR. ${ }^{5}$ This review is focused on seeing how the application of SLN can be a promising strategy to overcome or reduce the occurrence of antimicrobial resistance (AMR). The main topics of discussion include the characteristics and structure of SLN, pharmacokinetic properties, AMR mechanism, and SLN mechanism in reducing microbial resistance ability.

\section{DISCUSSION}

\section{Solid Lipid Nanoparticle (SLN)}

Solid lipid nanoparticles are spherical colloidal drug delivery systems with diameters ranging from 40-1000 $\mathrm{nm} .{ }^{6}$ The main components of SLN are a biodegradable physiological lipid such as glycerides, sterols, fatty acids, and waxes with a ratio $0.1 \%(\mathrm{w} / \mathrm{w})$ to $30 \%(\mathrm{w} / \mathrm{w})$. The lipid is used as a nanoparticle matrix which is supported by lipid properties that can solidify at room temperature. Another important component of SLN is surfactants with a concentration of $0.5 \%(\mathrm{w} / \mathrm{w})$ to $5 \%(\mathrm{w} / \mathrm{w})$ which is used to stabilize the dispersion of lipid in liquid medium. ${ }^{7}$ Additionally, the material used for SLN preparation has a generally recognized as safe (GRAS) status approved by FDA. ${ }^{8}$

\section{Types of SLN}

In general, the structure of SLN is presented in FIGURE 1. Based on drug incorporation position, SLN is classified into three models 1) SLN type 1 or homogenous matrix model, characterized by uniformly dispersed drug in the lipid matrix; 2) SLN type 2 or drug-enriched shell model, characterized by the drug concentrated in the still liquid outer part, and 3) SLN type 3, drug-enriched core model, characterized by the drug that concentrated in the core part of SLN.

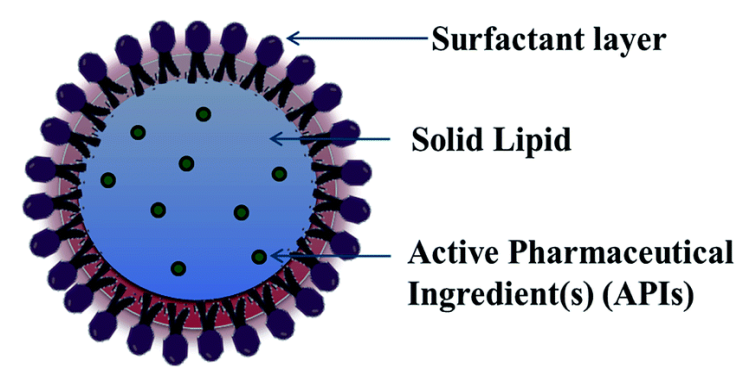

FIGURE 1. The structure of SLN. ${ }^{9}$

The position of drug incorporation can significantly affect drug release from nanoparticles. Homogenous matrix model and drug enriched core model are suitable for controlled release, while drug-enriched shell model is suitable for burst release. These models and their release system can be prepared by various methods. ${ }^{10}$

\section{Preparation of SLN}

Solid lipid nanoparticles and drug incorporation can be prepared by hot homogenizationand coldhomogenization methods which are the most common methods in SLN production. ${ }^{12}$ In the hot homogenization method, the lipid must be melted at $5-10^{\circ} \mathrm{C}$ above its melting point to solubilize the drug. The drugcontaining melt is then dispersed into a hot surfactant solution to obtain preemulsion. To produce nanoemulsions, pre-emulsion is homogenized at high pressure (500-1500 bar) and upon cooling at room temperature, nanoemulsions are solidified to form solid lipid nanoparticles (FIGURE 2). ${ }^{13}$ 


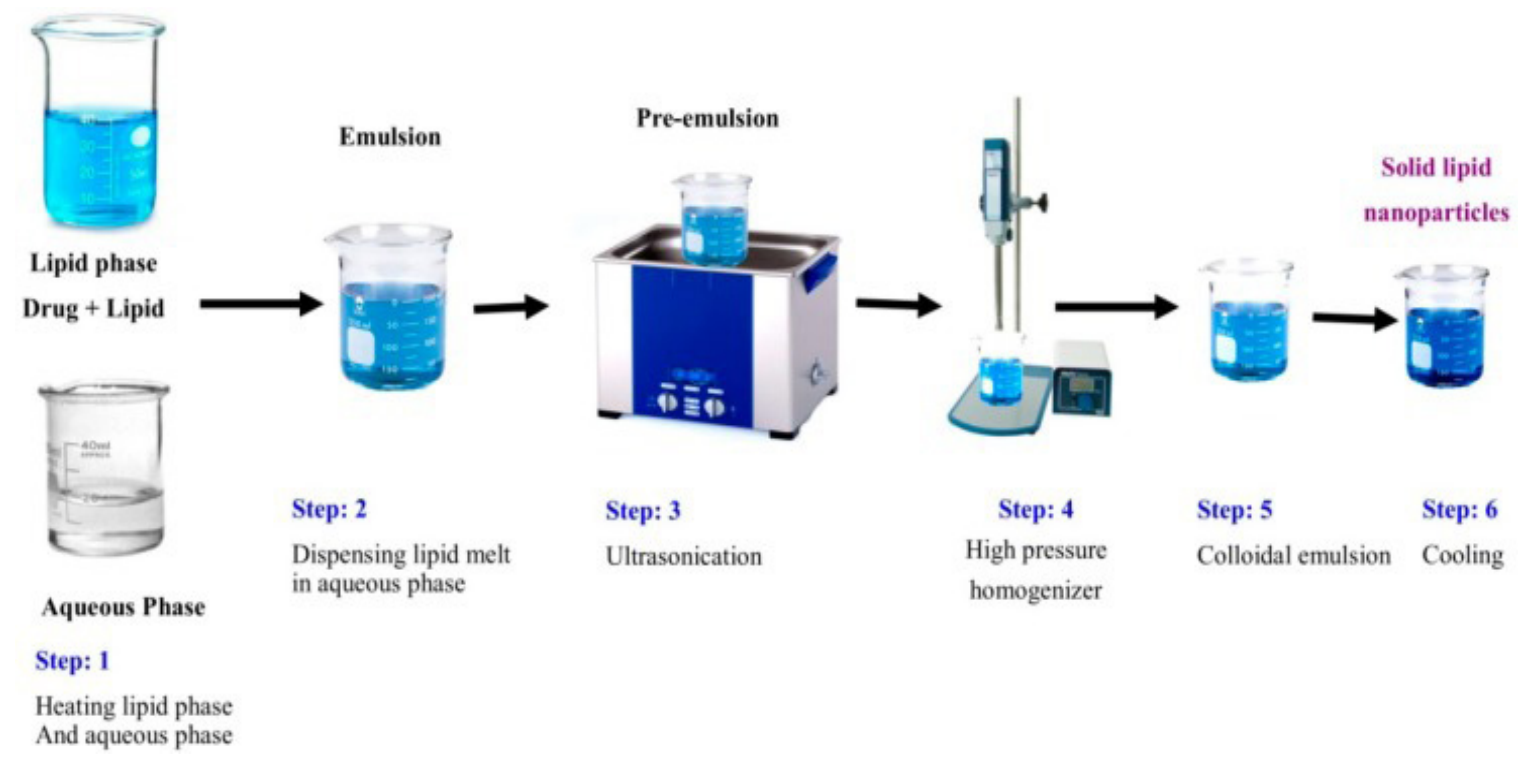

FIGURE 2. Hot homogenization method

In high temperature from hot homogenization process may cause degradation of temperature-sensitive drugs. Therefore, cold homogenization is more suitable than hot homogenization to incorporate these drugs into nanocarriers. This method performs rapid cooling using liquid nitrogen or dry ice to obtain solid solution. The solution is then converted into microparticle and dispersed into cold surfactant solution. In the next step, high pressure is applied to microparticle at room temperature to produce solid lipid nanoparticle. ${ }^{14}$

\section{Pharmacokinetic Properties of SLNs}

\section{Absorption}

Solid lipid nanoparticles possess physical and chemical properties that improve drug stability in gastrointestinal (GI) tract. The small size of SLNs can increase surface area and provide bioadhesion at the intestinal wall. The ability to perform bioadhesion can prolong the residence time of the drug and maintain close contact with epithelial membrane, resulting in better absorption. In addition, triglycerides, the main component of SLNs, will undergo hydrolysis by lipase to produce mono-and diacylglycerol. Mono- and diacylglycerol then induce bile salt secretion to form a structure called micelle that enhances drug absorption. ${ }^{15}$ Furthermore, SLNs also induce chylomicron formation which is secreted into lymphatic system. Drugs are then transported through lymphatic system to avoid first-pass metabolism. ${ }^{16}$

\section{Biodistribution}

Encapsulation with SLNs can affect drugs absorption and transport pathway. The difference between long-chain triglycerides and mediumchain triglycerides also has an impact on intestinal uptake and lymphatic transportation. The SLNs with longchain triglycerides require the formation of chylomicron for transport via lymphatic circulation which can increase drug bioavailability, while SLNs with medium-chain do not induce chylomicron formation. ${ }^{17}$ The uptake of SLNs into lymphatic system can occur via two mechanisms: M-cell-mediated uptake and paracellular/transcellular route. ${ }^{18}$ Basically, SLN properties such as particle size and shape can affect their bioavailability. Small particles tend to adhere to cell-surface while large particles (>200 $\mathrm{nm}$ ) are filtered out by reticular meshwork. ${ }^{19}$

The capability of SLNs to enter blood circulation through lymphatic system 
leads to differences in the distribution of the drug incorporated into SLN with conventional drugs. Luo et al. ${ }^{20}$ reported that the oral administration of puerarin in SLN (Pue-SLN) showed a higher concentration compared to convention puerarin (the $\mathrm{C}_{\max }$ for Pue-SLNs were 2.06 times of conventional puerarin). Conventional puerarin reached $\mathrm{C}_{\max }$ in rats around $110 \mathrm{~min}$ while the time to reach $\mathrm{C}_{\max }$ for Pue-SLNs was about 40 min. For the tissue concentration-time profiles, the Tmax value of Pue-SLNs was $1 \mathrm{~h}$ in the liver, spleen, kidney, and lung, $6 \mathrm{~h}$ in the heart, and $2.5 \mathrm{~h}$ in the brain. Increased concentration of puerarin in the lung and heart indicates a protective effect against cardiocerebrovascular disease. In a separate study by Wang et al. ${ }^{19}$ using another substance (genoposide), it was reported to have similar results. The concentration of genoposide loaded into SLN was increased in various tissues, especially in the target organs such as liver, spleen, lung, and brain. The ability of SLN to penetrate the bloodbrain barrier (BBB) is probably due to the interaction of SLN with ApoE, Apo C-II, albumin, and immunoglobulin G which belong to brain-specific targets. In addition, genoposide-SLN with its small size (116.5 $\mathrm{nm}$ ) can pass through the reticuloendothelial system causing prolonged circulation time.

\section{Elimination}

Incorporation of drug can lead to alteration in the drug excretion pattern. Excretion of drug usually becomes slower after the oral administration of SLN drug resulting in a decrease of clearance rate. These alterations can be caused by two factors 1) properties of SLN that allow particles to perform bioadhesion thereby prolonging the residence time of the drug in the GI tract; and 2) the tendency of SLNs to enter lymphatic system thus avoiding first-pass metabolism which in turn increases bioavailability and reduces the clearance of drugs..$^{20,21}$

\section{Antibiotic Resistance Mechanism}

Antibiotic resistance can develop both naturally and acquired. Natural resistance occurs intrinsically, where it is always expressed on bacteria without prior exposure to antibiotics, or induced, where bacteria expressing resistance after antibiotic exposure. In intrinsic resistance, the mechanism is mainly caused by reduced permeability of bacterial cell membrane, especially on Gram-negative bacteria which has lipopolysaccharide on the cell membrane, and efflux pump activity. Acquired resistance is caused by horizontal genetic material transfer from one bacterium to another, by either transformation, transposition, or conjugation. DNA mutation on bacterial chromosomes can also cause resistance. Resistance gene transmitted mainly by plasmid.

There are 4 main mechanisms in resistance i.e. 1) limiting drug uptake; 2) drug target modification; 3) drug inactivation; and 4) active drug efflux. Intrinsic resistance can occur by limiting uptake, drug inactivation, and drug efflux. Meanwhile, acquired resistance can be done by drug target modification and drug efflux. There are different mechanisms between Gram-negative and Gram-positive bacteria because of their different membrane structure. Gramnegative bacteria can reach resistance by all those mechanisms stated above, but on Gram-positive bacteria there is no resistance caused by limiting uptake and some mechanisms of drug efflux. ${ }^{22}$

\section{Limiting uptake}

Characteristics of bacteria affect antibiotic uptake. On Gram-negative bacteria which have lipopolysaccharide, the cell membrane acts as a barrier against certain molecule, so that Gramnegative bacteria are resistant against drug withlarge molecule. Mycobacterium has an outer membrane with high lipid content which allow hydrophobic drug 
to enter its cell. Gram-positive bacteria do not have an outer membrane so there is no resistance caused by limiting drug uptake. Bacteria with no cell wall like Mycoplasma are resistant to antibiotics targeting cell walls like glycopeptide and $\beta$-lactam. ${ }^{22}$

\section{Drug target modification}

Bacteria can experience changes that occur on antibiotic targets. These changes can be point mutation on genes which coding target site, enzymatic changes on binding site, and replacement/bypass on target. ${ }^{23}$ All those mechanisms reduced the affinity between antibiotics and their target. For example, mutation on $r p s L$ gene which is located on $M$. tuberculosis chromosome that codes ribosomal protein $12 \mathrm{~s}$ caused MTB resistance to streptomycin. On MRSA and $S$. pneumoniae resistant to penicillin there is a mutation on PBP which reduce $\beta$-lactam antibiotic's affinity to the target.

\section{Inactivation of antibiotic by bacterial enzyme}

Bacteria can inactivate or degrade antibiotics by producing enzymes that cause hydrolysis, redox reaction, or modification of chemical groups. One of the most known enzymes is $\beta$-lactamase, which inactivates antibiotics by cleaving the $\beta$-lactam ring. Extended-spectrum $\beta$-lactamase (ESBL) has total resistance to $\beta$-lactam antibiotics. There are more than 180 types of ESBL that have been identified, and they are found in E. coli, Proteus mirabilis, and K. pneumoniae. ${ }^{24}$

\section{Efflux pump}

Bacteria can form a system which pumps toxic substance out of their cells to extracellular environment. Efflux pump system was first found on the beginning of 1980s, where E. coli can expel tetracycline out of its cytoplasm with efflux pump. Efflux pump is present on both Gram-positive and Gram-negative bacteria. Efflux pump can either be specific to a substrate or nonspecific to some substrate (broad substrate specificity). Broad substrate specificity can be found on MDR bacteria. Efflux pump protein is coded by genes on mobile genetic element (MGE) or chromosome. Resistance mechanism by efflux pump occurs to various types of antibiotics like protein synthesis inhibitor, fluoroquinolone, $\beta$-lactam, carbapenem, and polymyxin. ${ }^{22}$

\section{Biofilm-based AMR}

Biofilm is a bacterial defense mechanism against the environment by forming a layer of extracellular polymeric dense matrix composed of various bacteria species which adheres to a surface. Biofilm-forming bacteria have 1000 -fold resistance compared to planktonic bacteria. Antibiotic resistance caused by biofilm formation has 2 main mechanisms i.e. 1) bacteria are protected from antibiotic penetration by biofilm layer; 2) physiological changes in biofilmforming bacteria, like slowed growth until dormant phase. S. aureus including MRSA are bacteria that is most likely to form biofilm. ${ }^{25}$ Biofilm formation can reduce the susceptibility of sensitive bacteria that are part of biofilm. ${ }^{26}$

\section{SLN/NLC Mechanism to Overcome AMR}

The use of nanocarrier as a drug vehicle can overcome problems related to biological barriers like AMR mechanism. ${ }^{27}$ Solid lipid nanoparticles allow higher surface contact which increases the permeability of cell membrane to drugs and efflux pump. Solid lipid nanoparticles can deliver poorly water-soluble drug and have higher efficiency in encapsulating watersoluble antibiotic. Some studies had been conducted in vitro with SLN as an antibiotic carrier. Bazzaz et al. reported the use of rifampin carried on SLN against biofilm-forming $S$. epidermidis. It was inferred that the rifampin loaded SLN was able to reduce the biofilm mass as concentration increased. ${ }^{28}$ The nanoparticle may interact with the biofilm matrix and help remove bacterial 
biofilms. Severino et al. showed that SLNloaded polymyxin can be used effectively in resistant strains of $P$. aeruginosa. ${ }^{27}$ Vancomycin loaded in SLN can be held for up to $54 \mathrm{~h}$ and increase clearance of MRSA in murine models. ${ }^{29}$ Solid lipid nanoparticles improve antimicrobial activity by increasing drug permeation through bacterial cell wall and other barriers. They can reduce drug expulsion caused by efflux pump activity and protect antibiotics from enzymes that can modify antibiotics. However, there is no publication that explains about the protection of SLN against bacterial enzymatic activity. Furthermore, SLNs increase cell uptake of antibiotic because of its nano size.

Nanostructured lipid carrier (NLC) is the improved version of SLN, which has advantages like larger capacity and stability in carrying more amount of drug because its solid lipid component is replaced by oil. The disadvantage of SLN like drug expulsion caused by SLN polymorphism can be minimalized by NLC structure. Nanostructure lipid carrier has been used as an antibiotic vehicle. Vairo et al. studied NLC loaded with sodium colistimethate and amikacin in vitro and in vivo. The encapsulation process with NLC did not reduce the efficacy of both drugs and they were effective against extensively resistant $A$. baumanii. ${ }^{30}$ The size of NLCs and their charges increase the penetrability so that the drug can penetrate the biofilm. Muraca et al. reported that ciprofloxacin loaded NLCs are potent for P. aeruginosa biofilm infections. ${ }^{26}$

\section{CONCLUSION}

Solid lipid nanoparticles have been used as an antibiotic carrier and proven to be effective to be used on resistant bacterial strains in vitro. The use of NLC which is the enhanced form of SLN has a higher effectivity rate since it has larger capacities to carry more amounts of drug. Nanocarrier is quite promising for overcoming antibiotic resistance problem, but the effectiveness of antibiotic formulation with SLN/NLC carrier needs to be evaluated by clinical trial on patients.

\section{ACKNOWLEDGEMENTS}

We would like to thank our colleagues from Master of Biomedical Sciences, Faculty of Medicine, Public Health, and Nursing, Universitas Gadjah Mada, Yogyakarta for their support in the preparation of the manuscript.

\section{REFERENCES}

1. Beloqui A, Solinís MA, RodríguezGascón A, Almeida AJ, Préat V. Nanostructured lipid carriers: Promising drug delivery systems for future clinics. Nanomedicine 2016; 12(1):143-61.

ht tps://doi.org/10.1016/j. nano.2015.09.004

2. Qushawy M, Nasr A. Solid Lipid Nanoparticles (SLNs) as nano drug delivery carriers: preparation, characterization, and application. Int J App Pharm 2020; 12(1):1-9

h t tp s://d oi.org/10.22159/ ijap.2020v12i1.35312

3. Ghasemiyeh P, Samani SM. Solid lipid nanoparticles and nanostructured lipid carriers as novel drug delivery systems: applications, advantages and disadvantages. Res Pharm Sci 2018; 13(4):288-303.

https://doi.org/10.4103/17355362.235156

4. Christaki E, Marcou M, Tofarides A. Antimicrobial resistance in bacteria: Mechanisms, evolution, and persistence. J Mol Evol 2020; 88(1):26-40.

https://doi.org/10.1007/s00239-01909914-3

5. Arana L, Gallego L, Alkorta I. Incorporation of antibiotics into solid lipid nanoparticles: A promising approach to reduce antibiotic resistance emergence. Nanomaterials 2021; 11(1251):1-27. 
https://doi.org/10.3390/nano11051251

6. Naseri $\mathrm{N}$, Valizadeh $\mathrm{H}$, ZakeriMilani P. Solid lipid nanoparticles and nanostructured lipid carriers: structure, preparation and application. Adv Pharm Bull 2015; 5(3):305-13.

https://doi.org/10.15171/apb.2015.043

7. Borges A, de Freitas V, Mateus N, Fernandes I, Oliveira J. Solid lipid nanoparticles as carriers of natural phenolic compounds. Antioxidants 2020; 9(10):998

https://doi.org/10.3390/antiox9100998

8. Nair A, Shah J, Al-Dhubiab B, Jacob S, Patel SS, Venugopala KN, et al. Clarithromycin solid lipid nanoparticles for topical ocular therapy: optimization, evaluation and in vivo studies. Pharmaceutics 2021; 13(4):523

h t t p s://d o i.org/10.3390/ pharmaceutics13040523

9. Duan Y, Dhar A, Patel C, Khimani M, Neogi S, Sharma P, et al. A brief review on solid lipid nanoparticles: part and parcel of contemporary drug delivery systems. RSC Advances 2020; 10:26777-91.

https://doi.org/10.1039/D0RA03491F

10. Balamurugan $K$ \& Chintamani $P$. Lipid nano particulate drug delivery: An overview of the emerging trend. Pharma Innov J 2018; 7(7):779-89

11. Razak SAA, Gazzali AM, Fisol FA, Abdulbaqi IM, Parumasivam $\mathrm{T}$, Mohtar $\mathrm{N}$, et.al. Advances in nanocarriers for effective delivery of docetaxel in the treatment of lung cancer: An overview. Cancers 2021; 13(3):400.

https://doi.org/10.3390/cancers13030400

12. Alsaad A, Hussien A, Ghareeb M. Solid Lipid Nanoparticles (SLN) as a novel drug delivery system: a theoretical review. Sys Rev Pharm 2020; 11(5):259-73.

https://doi.org/10.31838/srp.2020.5.39

13. Gupta S, Kesarla R, Chotai N, Misra A, Omri A. Systematic approach for the formulation and optimization of solid lipid nanoparticles of efavirenz by high pressure homogenization using design of experiments for brain targeting and enhanced bioavailability. BioMed Res Int 2017; 5984014.

https://doi.org/10.1155/2017/5984014

14. Mishra V, Bansal KK, Verma A, Yadav N, Thakur S, et al. Solid lipid nanoparticles: emerging colloidal nano drug delivery systems. Pharmaceutics 2018; 10(4):191.

h t t p s://d oi .org/10.3390/ pharmaceutics10040191

15. Qi J, Lu Y, Wu W. Absorption, disposition and pharmacokinetics of solid lipid nanoparticles. Curr Drug Metab 2012 May 1;13(4):418-28.

$\mathrm{h}$ t $\mathrm{t}$ p s : / / d 0 i . org/10.2174/138920012800166526

16. Zhang Z, Lu Y, Qi J, Wi W. An update on oral drug delivery via intestinal lymphatic transport. Acta Pharm Sin B 2021; 11(8):2449-68.

h t tp s://doi.org/10.1016/j . apsb.2020.12.022

17. Makwana V, Jain R, Patel K, Nivsarkar M, Joshi A. Solid Lipid Nanoparticles (SLN) of Efavirenz as lymph targeting drug delivery system: Elucidation of mechanism of uptake using chylomicron flow blocking approach. Int J Pharm 2015; 495(1):439-46.

h t tps://doi.org/10.1016/j. ijpharm.2015.09.014

18. Hassan H, Bello R, Adam SK, Alias E, Affandi $M$, Shamsuddin $\mathrm{AF}$, et al. Acyclovir-loaded solid lipid nanoparticles: optimization, characterization and evaluation of its pharmacokinetic profile. Nanomaterials 2020; 10(9):1785 https://doi.org/10.3390/nano10091785

19. Wang F, Cao J, Hao J, Liu K. Pharmacokinetics, tissue distribution and relative bioavailability of geniposide-solid lipid nanoparticles following oral administration. J Microencapsul 2014; 31(4):382-9. https://doi.org/10.3109/02652048.201 3.863396

20. Luo CF, Yuan M, Chen MS, Liu SM, Zhu 
L, Huang BY, et al. Pharmacokinetics, tissue distribution and relative bioavailability of puerarin solid lipid nanoparticles following oral administration. Int J Pharm 2011; 410(1-2):138-44.

h t tps://doi.org/10.1016/j . ijpharm.2011.02.064

21. Purvin S, Vuddanda PR, Singh SK, Jain A, Singh S. Pharmacokinetic and tissue distribution study of solid lipid nanoparticles of zidovudine in rats. J Nanotechnol 2014; 1-7. https://doi.org/10.1155/2014/854018

22. Reygaert WC. An overview of the antimicrobial resistance mechanisms of bacteria. AIMS Microbiol 2018; 4(3):482-501.

h t tps: / / d o i.org / 10.3934 / microbiol.2018.3.482

23. Munita JM, Arias CA. Mechanisms of antibiotic resistance. Microbiol Spectr 2016; 4(2):10.1128/ microbiolspec.VMBF-0016-2015.

h t t p s://d o i.org/10.1128/ microbiolspec.VMBF-0016-2015

24. dos Santos RMA, de Toledo LG, Spósito L, Marena GD, de Lima LC, Fortunato GC, et al. Nanotechnologybased lipid systems applied to resistant bacterial control: A review of their use in the past two decades. Int J Pharm 2021; 603.

h t tps://doi.org/10.1016/j. ijpharm.2021.120706

25. Vanamala K, Tatiparti K, Bhise K, Sau S, Scheetz MH, Rybak MJ, et al. Novel approaches for the treatment of methicillin-resistant Staphylococcus aureus: Using nanoparticles to overcome multidrug resistance. Drug Discov Today 2021; 26(1):31-43. ht tp s://doi.org/10.1016/j . drudis.2020.10.011
26. Muraca GS, Soler-Arango J, Castro GR, Islan GA, Brelles-Mariño G. Improving ciprofloxacin antimicrobial activity through lipid nanoencapsulation or non-thermal plasma on Pseudomonas aeruginosa biofilms. J Drug Deliv Sci Technol 2021; 64:102644.

h t tps://doi.org/ $10.1016 /$ j . jddst.2021.102644

27. Severino P, Silveira EF, Loureiro K, Chaud MV, Antonini D, Lancellotti $\mathrm{M}$, et al. Antimicrobial activity of polymyxin-loaded solid lipid nanoparticles (PLX-SLN): Characterization of physicochemical properties and in vitro efficacy. Eur J Pharm Sci 2017; 106:177-84.

https://doi.org/10.1016/j.ejps.2017.05.063

28. Mullis AS, Peroutka-Bigus N, Phadke $\mathrm{KS}$, Bellaire BH, Narasimhan B. Nanomedicines to counter microbial barriers and antimicrobial resistance. Curr Opin Chem Eng 2021; 31:100672.

h t tps://doi.org/10.1016/j. coche.2021.100672

29. Malaekeh-Nikouei B, Fazly Bazzaz BS, Mirhadi E, Tajani AS, Khameneh B. The role of nanotechnology in combating biofilm-based antibiotic resistance. J Drug Deliv Sci Technol 2020; 60:101880.

h t tps://d oi.org/10.1016/j . jddst.2020.101880

30. Vairo C, Basas J, Pastor M, Palau M, Gomis X, Almirante $\mathrm{B}$, et al. In vitro and in vivo antimicrobial activity of sodium colistimethate and amikacin-loaded nanostructured lipid carriers (NLC). Nanomedicine 2020; 29:102259.

ht tps://doi.org/10.1016/j . nano.2020.102259. 